DOI: 10.46340/eujem.2020.6.4.3

Maryna Naumova, PhD in Physics and Mathematics

ORCID ID : https://orcid.org/0000-0002-1333-8022

Vasyl' Stus Donetsk National University, Ukraine

\title{
MODELING AS A TOOL OF SOCIO-ECONOMIC MANAGEMENT IN THE CONDITIONS OF INSTABILITY
}

\author{
Марина Наумова, к.ф.-м.н. \\ Донецький національний університет імені Василя Стуса, Україна

\section{МОДЕЛЮВАННЯ ЯК ІНСТРУМЕНТ \\ СОЦІАЛЬНО-ЕКОНОМІЧНОГО УПРАВЛІННЯ В УМОВАХ НЕСТАБІЛЬНОСТІ}

\begin{abstract}
Our country and the whole world can cope with the challenges of our time only by embarking on an innovative path of development. It is possible to increase the efficiency and quality of management activities in the state, at enterprises and organizations, to ensure the technological independence of our country only if we use adequate mathematical methods and build reliable forecasts on their basis. This article is devoted to the analysis of methods for modeling and forecasting complex socio-economic systems in times of crisis and instability. The paper presents a classification of existing approaches to the construction of models and forecasts of economic processes, their scope. Methods that have a theoretical basis for a more correct description of socio-economic instability and methods that can be applied only partially are highlighted. It is noted that a combination of various mathematical methods in conjunction with software will provide the most accurate modeling results for making rational management decisions.

Keywords: mathematical modeling, management, instability, socio-economic system, risk.
\end{abstract}

Постановка проблеми. Невід'ємною складовою переходу економіки від планової до ринкової $€$ необхідність підвищення якості управлінської функції в процесі планування та регулювання виробничих і технологічних циклів, прогнозування їх майбутньої траєкторії розвитку. В умовах соціально-економічної нестабільності вдосконалення управління економікою взагалі i підприємницькою діяльністю зокрема не обходиться без застосування математичних методів і цифрових комп'ютерних технологій. У зв'язку з цими завданнями сучасної економіки і управління постійно зростає актуальність створення, вдосконалення і використання економіко-математичних методів і моделей для вирішення першочергових питань.

За допомогою економіко-математичного моделювання можна проводити імітації процесів функціонування соціально-економічних систем, робити аналіз і оцінювання, виявляти взаємозв'язки між елементами системи, прогнозувати закономірності та динаміку процесів, планувати майбутню діяльність. Цінність математичних методів полягає в можливості ефективного структурування вихідної інформації, доступного подання результату для проведення подальшого дослідження. Головною рисою застосування методів математики $€$ можливість опису соціально-економічної системи за допомогою моделі, при побудові якої можна враховувати фактори нестабільності їх ризиків, будувати стратегії, пропонувати методи управління, порівнювати результати різних варіантів відповідних рішень. Взагалі, соціально-економічна нестабільність несе в собі елементи невизначеності вихідної інформації та можливість ризиків, ймовірність яких необхідно враховувати при побудові моделі функціонування складної економічної системи.

Принципове значення при застосування економіко-математичного моделювання має те, що реальна соціально-економічна система, яка не може бути описана точно і в повній мірі, відтворюється у вигляді цілком придатної для дослідження моделі, можливо, навіть і складної, але доступної для комп'ютерних розрахунків. Важливим $€$ те, що в той же час вона містить в собі всі ключові властивості і взаємозв'язки, що описують систему. При використанні отриманої моделі можна комбінувати різні 
вхідні величини, параметри процесу, експериментувати з можливими наслідками управлінських рішень та знаходити оптимальні шляхи майбутнього для виконання поставлених орієнтирів.

Аналіз останніх досліджень i публікацій. Моделювання в економіці $\epsilon$ потужним інструментом в дослідженнях проблем функціонування соціально-економічних систем в умовах нестабільності та невизначеності. Багато праць закордонних та вітчизняних вчених присвячено вивченню цих аспектів економічної теорії та практики в розрізі різних сфер економіки та типів моделей. Моделювання як інструмент в управлінні діяльністю банку та фінансовій сфері з урахуванням ризиків є предметом дослідження таких вчених, як Борисова С.Є., Балашова О.В. ${ }^{1}$, Ставицький О.В., Мозолевська M.O. ${ }^{2}$ Оцінювання конкурентоспроможності підприємства та економіко-математичне моделювання виробничої діяльності розглянуто в працях Фартушного І. Д., Пузирної К. М. ${ }^{3}$, Федоряка Р.М., Тимченко О.П. ${ }^{4}$ Застосування економіко-математичних методів в маркетинговій діяльності розглядається в працях Коломицевої О.В., Бурцевої Т.І., Пальонни Т.А. 5 . Побудові математичних моделей в дослідженнях сільського господарства присвячено роботи Сидор Г.В. ${ }^{6}$, Пласконь С.А., Кармелюк Г.І., Сенів Г.В. ${ }^{7}$, Лобода О.М., Кавун Г.М. ${ }^{8}$ Ринок праці та сфера соціально-трудових відносин в умовах нестабільності також є об'єктом економіко-математичного моделювання та прогнозування в роботах Журавки А.В. ${ }^{9}$, Дупляка О.М., Єдлічко А.O. ${ }^{10}$ Ретроспективний огляд математичних методів та підходів, виділення найбільш далекосяжних з точки зору впровадження в процеси державного управління здійснено в роботі Вертелєвої О.В. ${ }^{11}$

Метою даної статті $\epsilon$ аналіз методів моделювання та прогнозування складних соціальноекономічних систем в умовах кризи та соціально-економічної нестабільності.

Основною метою використання економіко-математичних методів i моделей $\epsilon$ науковообгрунтоване визначення ключових напрямів управлінської діяльності для отримання найбільшої ефективності в процесі прийняття рішень. При грамотному застосуванні математичних методів в економіці можна суттєво підвищити якість планування, розробки стратегії і тактики, отримати додатковий ефект без залучення в процес додаткових ресурсів.

Існує багато способів класифікації методів моделювання, однак варто відмітити деяку умовність цього поділу, оскільки одна і таж сама модель може відноситись до декількох класів. Якщо ж розглядати характер методу, на принципах якого будується моделювання в економіці, то можна виділити такі основні типи:

- економіко-математичне моделювання;

- моделювання на основі системного аналізу;

\footnotetext{
${ }^{1}$ Борисова С.С., Балашова О.В. (2017). Економіко-математичне моделювання та прогнозування обсягів кредитних і залучених коштів банківської установи. Економічний вісник Донбасу, 3 (49), 75-82.

${ }^{2}$ Ставицький, О. В., Мозолевська, М. О. (2017). Використання нейронного мірежу для прогнозування у фінансових сферах. Актуальні проблеми економіки та управління, 11. <https://eujem.cz/wp-content/uploads/ 2020/eujem_2020_6_3/09.pdf> (2020, липень, 28).

${ }^{3}$ Фартушний, І. Д., Пузирна, К. М. (2017). Економіко-математічне моделювання виробничої діалії підприемства легкої промисловості. Економічний вісник НТУУ "КПI", 14. <http://ev.fmm.kpi.ua/article/view/108705> (2020, липень, 28).

${ }^{4}$ Федоряк, Р. М., Тимченко, О. П. (2015). Економіко-математічне моделювання окинювання конкурентоспроможності підприемства в умовах економічної кризи. Формування ринкових видносин в Україні, 12 (175), 133-137.

${ }^{5}$ Коломіцева О.В., Бурчева Т.І., Палонна Т.А. (2016). Економіко-математичні методи в маркетинговій діяльності підприємства. Збірник наукових праць Черкаського державного технологічного університету. Серія: Економічні науки, 41 (1), 5-9.

${ }^{6}$ Сидор, Г. В. (2016). Економічне моделювання моделювання процесу кредитування сільськогосподарського виробництва. Вісник ОНУ імені I.I. Мечникова, 21, 7 (1), 187-191.

${ }^{7}$ Пласкон, С. А., Кармелюк, Г. І., Сенів, Г. В. (2016). Математичне моделювання процесу функціонування аграрного формулу. Економічний аналіз, 26, 1, 156-162.

8 Лобода, О. М., Кавун, Г. М. (2019). Економіко-математичні моделі для розрахунку оптимальної спеіалізації аграрних підприємств. Науково-виробничий журнал Бізнес-навігатор, 5-2, 141-145.

9 Журавка, А. В., Мудаширу, Т. М. (2017). Моделі нелінійної динаміки в вирішенні проблеми макроекономічної нестабільності на ринку практики капіталу. Молодий вчений, 4,4, 51-55.

10 Дупляк, О. М., Сдлічко, А. О. (2016). Аналіз підходів робити моделювання та прогнозування заробної плати. Науковий вісник Ужгородського національного університету. Серія: Міжнародні економічні видимості та світове господарство, 6 (1), 117-119.

${ }^{11}$ Вертєльєва О.В. (2019). Математичне моделювання економічного процесу проходить в умовах парадигмальних зрушень. Інвестиціï: практика та досвід, 12, 48-56.
} 
- методи прогнозування з урахуванням суб’єктивної думки експертів;

- методи інтелектуального аналізу даних.

Слід зауважити, що, всі відмічені типи моделювання базуються на використанні математики. В залежності від цілей і вихідних даних, кожен з методів можна використовувати для вирішення різних за проблематикою завдань. I навпаки, для розв'язання конкретної проблеми можна застосовувати різні математичні методи. В даний час особливої актуальності набувають комбіновані моделі, які дозволяють застосовувати кілька способів моделювання і отримати більш адекватні результати. Якщо ж модель повинна описувати процес функціонування соціально-економічної системи в умовах нестабільності, кризи та зростаючих ризиків, то при введенні вихідної інформації в модель виникає невизначеність, яка потребує додаткового врахування.

До економіко-математичного моделювання можна віднести: методи класичного математичного аналізу, методи дослідження операцій, моделювання на основі теорії ймовірностей та математичної статистики, побудову балансових моделей, застосування теорії графів, мережеві моделі, застосування методів нечіткої логіки.

Класичні методи математичного аналізу застосовують при обрахунках різноманітних показників, при побудові виробничих функцій (найвідоміша 3 них - функція Коба-Дугласа), функцій попиту та пропозиції, дослідженнях поведінки динамічних систем, визначенні точки ринкової рівноваги, проведенні маржинального аналізу, визначенні еластичності функцій тощо.

Дослідження операцій являє собою математичний інструментарій, теорію математичних моделей і методів, які використовуються для обгрунтування та прийняття оптимальних рішень в різних областях людської діяльності. Дослідження операцій передбачає формалізований опис операції і кількісний аналіз чинників, що визначають досягнення поставлених в операції завдань. У число методів дослідження операцій зазвичай входять: класичні методи оптимізації, математичне програмування, яке включає в себе лінійне та нелінійне програмування, стохастичне, динамічне i евристичне програмування, теорію мережевого планування, теорію управління запасами, теорію ігор. Методи дослідження операцій мають широке застосовуння в задачах аналізу, вибору оптимальних рішень та прогнозування в самих різних областях економіки: планування і оперативне управління виробництвом, управління запасами, управління персоналом, розподіл матеріальних ресурсів, планування та розміщення активів, формування портфеля замовлень, керівництво інноваційним проектом тощо. Оптимізаційні моделі $\epsilon$ методом пошуку найкращих (оптимальних) рішень конкретної економічної задачі і описують умови функціонування економічної системи. Найкращий варіант споживання, розподілу чи виробництва з найоптимальнішім використанням ресурсів можна визначити за допомогою побудови оптимізаційної моделі. Перші роботи у цьому напрямку пов'язані 3 іменами Л. Канторовича, Дж. Данціга ${ }^{1}$, Л. Канторовича, Р. Гоморі та інших.

В ситуаціях, коли невизначеність $є$ однією з головних рис вихідної інформації, при дослідженні економічних систем застосовуються методи стохастичного та евристичного програмування (А. Ньюелл, Дж. Шоу, Г. Саймон). До них відносяться задачі організації і управління виробництвом, рухом товару, проблеми планування і проектування, знаходження ефективної системи розстановки працівників і розподілу завдань, задач контролю за станом запасів, задач, що виникають в системах постачання запасними частинами тощо. Інший підхід полягає в використанні теорії нечітких множин при моделюванні проблем з невизначеностями, де фактори нестабільності описуються в термінах таких множин ${ }^{2}$. При побудові моделі отримують нечітку оптимізаційну задачу, яка дозволяє адекватно описати економічну систему, яка функціонує в кризових умовах.

Для оптимізації складних багатовекторних комплексів робіт, їх планування і управління за умови витрат обмежених ресурсів та участі великої кількості виконавців, застосовуються методи мережевого планування (метод оцінки і аналізу планів PERT, метод критичного шляху CPM). Основним напрямом мережевого планування $\epsilon$ мінімізація тривалості проекту, таким чином, підгрунтям для використання мережевих моделей є необхідність вдосконалення управлінської діяльності масштабними економічними проектами, виробництвом тощо.

Загальні методи розв'язання задач, які розглядають проблеми знаходження єтапів постачання та накопичення запасів, зберігання продукції при незадоволеному попиті на неї за умови збереження мінімальних сумарних витрат, об’єднує в собі теорія управління запасами.

\footnotetext{
${ }^{1}$ Dantzig G. B. and Thapa M. N. (1997). Linear programming. Springer-Verlag, Vol. 1., Introduction.

${ }^{2}$ Kumar A. (2011). A new method for solving fully fuzzy linear programming problems. Applied Mathematical Modelling, 35, 2, 817-823.
} 
Моделі і методи теорії ігор застосовуються в задачах прийняття рішень та аналізу в умовах нестабільного середовища. Основною метою цієї теорії $є$ побудова стратегії поведінки сторін, які знаходяться в процесі конкурентної боротьби або конфлікту (Дж. фон Нейман, О. Моргенштерн ${ }^{1}$, Дж. Неш). Вона застосовується при розв'язанні проблем конкуренції та дизайну ринків, ефективного розміщення ресурсів, ціноутворення тощо.

Сучасні дослідження економічних процесів та явищ не обходяться без застосування методів теорії ймовірностей та математичної статистики. Теоретичні основи теорії ймовірностей та статистики, їх додатки $€$ науковим підгрунтям для проведення аналізу вихідних даних, моделювання динаміки основних економічних показників, до яких відносять статистику випадкових величин, непараметричну статистику, багатовимірний статистичний аналіз, економетрику, статистику часових рядів і випадкових процесів, статистику об'єктів нечислової природи, статистику інтервальних даних, теорію масового обслуговування.

Застосування методів теорії ймовірностей і математичної статистики дозволяє виявити фактори, які $є$ найбільш значущими для вивчення соціально-економічної системи, здійснити оцінку параметрів економічного процесу, їх законів розподілу, побудувати математичну модель, яка буде враховувати стохастичну природу явищ і процесів, спрогнозувати на основі моделі достатньо достовірні значення кількісних характеристик. Ці методи знаходять величезне застосування у всіх сферах економіки, використовується, наприклад, при плануванні і організації виробництва, аналізі стану ринку праці, контролю якості роботи персоналу та вирішенні багатьох інших прикладних задач.

Більшість економічних процесів може бути охарактеризована набором багатовимірних статистичних даних. Якість і повнота аналізу структури та розвитку процесу залежать від досконалості методів дослідження емпіричних даних. Багатовимірний статистичний аналіз володіє широким спектром методів, спрямованих на визначення структури і взаємозалежності економічних факторів, етіології і наслідків функціонування економічних процесів: факторний аналіз, дискримінантний аналіз, кластерний аналіз (ієрархічний алгоритм), багатовимірне шкалювання, методи контролю якості, дерева рішень, латентно-структурний аналіз. Все це, при високому рівні стохастичности та волатильності економічних процесів, дає можливість планування і прогнозування їх розвитку з певною ймовірністю.

Основними напрямками застосування методів багатовимірного статистичного аналізу в економіці є: оцінка інвестиційної привабливості регіонів, класифікація регіонів за соціальноекономічними показниками або рівнем життя населення, демографія, ринок праці, банківська справа, фінанси, страхування, виробництво, управління відносинами з клієнтами, комерція, маркетинг, фондовий ринок тощо.

Одним 3 нових напрямків прикладної статистики, який швидко розвивається в останні роки, є математична статистика інтервальних даних. Вона представляє методи математичної статистики аналізу процесів не з числовими статистичними даними, а з інтервальними значеннями випадкових величин, які, наприклад отримані з накопленням помилок вимірювання (Дж. Тьюки, П. Хьюбер). Математична статистика інтервальних даних є частиною теорії робастності статистичних процедур. Вона застосовується при плануванні експерименту, порівнянні альтернатив, прийнятті рішень в умовах інтервальної невизначеності тощо.

Економетричні методи, включаючи теорію часових рядів, використовують при аналізі процесів в економіці та управлінні народним господарством, а також в різних областях науки і практики. Суть економетрики полягає в синтезі економіки та математичної статистики. Методи економетрики $€$ одними 3 найбільш затребуваних методів моделювання в економіці та посідають не останнє місце в світовій науці. Про це, зокрема, свідчить те, що економетрики Ян Тільберген і Рагнар Фріш (1969р.), Т. К. Купманс (1975 р.), Лоуренс Клейн (1980р.), Трюгве Хаавельмо (1989), Дж. Хекман и Д. Макфеден (2000) і інші отримали Нобелівські премії з економіки.

За допомогою економетрики вирішується дуже широке коло таких задач, як прогноз соціальноекономічних показників, які описують стан і динаміку економічної системи르, побудова різноманітних сценаріїв розвитку системи, при варіації взаємозв'язків між характеристиками системи та врахування несприятливих впливів зовнішнього середовища. На макроекономічному рівні математичними засобами економетрики вивчають закономірності виробництва та використання валового

\footnotetext{
${ }^{1}$ Von Neumann, J., Morgenstern, O. (1944). Theory of games and economic behavior. Princeton University Press.

${ }^{2}$ Наумова, М. А. (2018). Аналіз перетворень у сфері зайнятості в умовах соціально-економічної нестабільності. Вісник Одеського національного університету. Серія: Економіка, 23, 2, 82-90.
} 
внутрішнього продукту, розвитку різних сфер економіки та фінансів. На мікроекономічному рівні економетричні методи дозволяють проаналізувати діяльність підприємств та фірм, обгрунтувати управлінські рішення, що приймаються керівниками.

Ще однією значною сукупністю методів оцінювання систем масового обслуговування та їх параметрів за допомогою теоретичних положень теорії ймовірностей $\epsilon$ теорія масового обслуговування. До процесу обслуговування відносять різні процеси діяльності в економічних, виробничих та інших системах, наприклад, потоки поставок продукції деякого підприємству, потоки покупців у торгівельних центрах, очікування в черзі транспортних засобів тощо.

До теорії графів відносять математичні методи, які дають можливість здійснення формального опису взаємозв'язків множини елементів - ресурсів, запасів, витрат тощо. Теорія графів застосовується для знаходження оптимального шляху, найкоротшого маршруту перевезення товару, для оптимізації виробничого процесу, для прийняття локально оптимальних рішень.

На основі теоретико-множинних та статистичних методів, з метою спроби опису системи, яка не має чітких границь функціонування, виникла теорія нечітких множин Л. Заде, яка поклала початок розвитку теорії нечітких формалізацій ${ }^{1}$. Було розроблено теорії нечітких систем, нечітка логіка, що дозволяє використовувати при обчисленнях як точні, так і приблизні значення змінних, нечіткі когнітивні моделі (Fuzzy Cognitive Maps), на яких базується більшість сучасних систем динамічного моделювання в області фінансів, політики і бізнесу.

Одним 3 перспективних методів моделювання соціально-економічних економічних систем $\epsilon$ моделювання на основі системного аналізу. Системний аналіз $є$ засобом дослідження систем зі складною ієрархічною структурою та високим рівнем якісної невизначеності. Він базується на загальній теорії систем та системному підході, методах досліджень із залученням математичної логіки, математичної статистики, теорії алгоритмів, теорії ігор, теорії ситуацій, теорії інформації, комбінаторики, евристичного програмування, імітаційного моделювання і ряду інших.

Системний аналіз знайшов широке застосування при моделюванні різних підсистем соціальноекономічної системи: при дослідженні і проектуванні складних технічних комплексів, при моделюванні процесів прийняття рішень в ситуаціях з великою початковою невизначеністю, при дослідженні та удосконаленні управління технологічними процесами, при дослідженні систем організаційного управління на рівнях підприємств, непромислових організацій, регіонів, держави в цілому, при вдосконаленні виробничих і управлінських підрозділів підприємств і організацій тощо. Ключовими завданнями системного аналізу $є$ побудова різних варіантів вирішення проблеми, з'ясування можливих ефектів, які може спричинити невизначеність в кожному з альтернативних сценаріїв і вибір оптимального варіанту враховуючи критерій ефективності.

У системному аналізі використовується сучасний математичний апарат і обчислювальні системи, однак для опису складних систем найчастіше використовують неформальні методи аналізу і синтезу. В даний час до системного аналізу відносять широкий діапазон методів, які можна об'єднати в такі класи: імітаційне динамічне моделювання (System Dynamics Symutation Modeling), ситуаційне моделювання, лінгво-комбинаторне моделювання, логіко-лінгвістичне моделювання, теорія інформаційного поля та інформаційних ланцюгів, системно-структурний синтез, когнітивний підхід, семіотичний підхід, методи аналогій.

Основним інструментом, що забезпечує об'єднання формальних і неформальних методів, $є$ імітаційне моделювання, до якого відносять системну динаміку, дискретно-подійне моделювання, агентне моделювання.

Системна динаміка (Systems Dynamics, запропонована у 1961 р Дж. Форрестером²) являє собою сукупність принципів і методів аналізу динамічних керованих систем зі зворотним зв'язком для вирішення виробничих, організаційних і соціально-економічних задач. За допомогою системної динаміки можна моделювати бізнес-процеси, виробництво, динаміку економічних процесів, популяції, екології, управлінську діяльність тощо. Системну динаміку найбільш ефективно використовувати при вирішенні наступних завдань:

- дослідження складних систем з метою виявлення причинно-наслідкових зв'язків;

- прогнозування наслідків зміни стратегій управління складною системою.

Дискретно-подійне моделювання (Дж. Гордон, 1960-ті роки) являє собою процес формування імітаційної моделі на основі послідовності операційних дій для точної побудови динамічної системи,

\footnotetext{
${ }^{1}$ Zadeh, L. A. (1965). Fuzzy sets. Information and Control, 8 (3), 338-353.

${ }^{2}$ Forrester, Jay. (1971). Counterintuitive behavior of social systems. Technology Review, 73(3), 52-68.
} 
що дозволяє виявити всі зовнішні і внутрішні фактори, які впливають на їі функціонування ${ }^{1}$. Цей тип моделювання має величезну сферу застосувань: логістичні, транспортні задачі, аналіз виробничих систем тощо. Ще одним методом імітаційного моделювання, який вивчає вплив поведінки об'єктів системи на функціонування всієї системи в цілому, є метод агентного моделювання. Агентні моделі можуть бути використані для опису споживчого ринку (в конкурентному середовищі ринку вибір агента-покупця залежить від індивідуальних особливостей і контактів з іншими агентами), процесу поширення епідемії (агенти - люди, які контактують з іншими людьми як носії інфекції, як володіють імунітетом, як перехворіли або сприйнятливі до хвороби), соціальних мереж і багатьох інших систем і процесів.

При розв'язанні таких задач, як аналіз і прогнозування споживчої поведінки, забезпечення ефективності реклами, розвиток брендів компанії, забезпечення продуктивної взаємодії персоналу компанії шляхом вдосконалення процесів внутрішньо корпоративного ділового спілкування, аналіз і прогнозування ринкових тенденцій, використовуються моделі економічної семіотики, яка займається описом інформаційних зв'язків в економіці. При розрахунках ймовірностей виникнення втрат та оцінці ризику проектів, які часто повторються, застосовується метод аналогій, який включає в себе аналіз аналогічної діяльності фірми у минулому.

При моделюванні процесу функціонування соціально-економічної системи за допомогою системного аналізу здійснюється сценарний аналіз і вибір найкращого варіанту розвитку, тому виникає необхідність сформувати множину альтернатив для цього вибору. Для вирішення таких задач використовують методи колективної генерації ідей, до яких відносять сучасні методи експертних оцінок, метод синектики (метод Гордона), морфологічний аналіз.

Сучасні методи експертних оцінок є затребуваними при відсутності рядів статистичних даних кількісних ознак показників економічного процесу, оскільки вони засновані на суб'єктивному експертному аналізі та прогнозуванні стану системи на основі раціональних та інтуїтивних міркувань. Ці група методів включає в себе метод Дельфі, мозковий штурм, метод середніх рангів, метод медіан, метод сценаріїв, метод аналізу ієрархій (запропонований в 1970 році американським математиком T.Л. Сааті), метод аналітичних мереж, методи QUEST, SEER. Прикладами процедур експертних оцінок $є$ методи оцінки майбутнього розвитку різноманітних підсистем економічної системи, регіонів та країни, доцільності фінансування науково-технічних проектів, розподіл фінансування, оцінювання при екологічних експертизах, в маркетингових дослідженнях.

Розвиток нових методологічних підходів і методів математичного моделювання складних соціально-економічних систем з урахуванням зовнішніх та внутрішніх викликів привів до виникнення методів, які можуть обробляти великі масиви даних, робити класифікації та прогнози, знаходити латентні закономірності та багато іншого - методи інтелектуального аналізу даних. До них відносять нейронні мережі, теорії нечітких множин і нечіткої логіки, генетичні алгоритми тощо, в основі яких відсутня умова про стаціонарність показників, що аналізуються і незмінність умов. Найбільш відомим i ефективним інструментом IАД $\epsilon$ нейронні мережі, який засновано на використанні теорії штучного інтелекту та інформатики.

Штучні нейронні мережі широко застосовуються для моделювання економічних та фінансових систем: прогнозування рівня попиту та обсягів продажів нових товарів і послуг, моделювання поведінки персоналу та клієнтів, визначення ймовірності банкрутства підприємства та банку, оцінка платоспроможності клієнта і ризику надання йому кредиту, прогнозування соціально-економічного розвитку територій тощо.

Проаналізувавши наведені підходи до моделювання складних соціально-економічних систем, можна відмітити, що жоден з методів не є універсальним, оскільки не може повністю описати всю складність економічного процесу, особливо коли система знаходиться у нестабільному або кризовому стані. Деякі з методів мають теоретичне підгрунтя для більш коректного опису соціально-економічної нестабільності, деякі методи можуть застосовуватись лише частково (рис. 1). Для підвищення якості моделювання необхідно комплексне застосування методів і підходів. Також варто зауважити, що переході системи до іншого стану, або при появі нових зовнішніх або внутрішніх викликів, виникає необхідність побудови нової моделі, можливо, із застосуванням зовсім інших підходів. Побудова моделі, неадекватної до реальної ситуації в умовах нестабільності, може привести до помилок при прийнятті рішень та управлінської діяльності.

\footnotetext{
${ }^{1}$ Matloff, N. (2008). Introduction to Discrete-Event Simulation and the SimPy Language. WEB.CS

$<$ https://web.cs.ucdavis.edu/ matloff/matloff/public_html/156/PLN/DESimIntro.pdf > (2020, Липень, 28).
} 


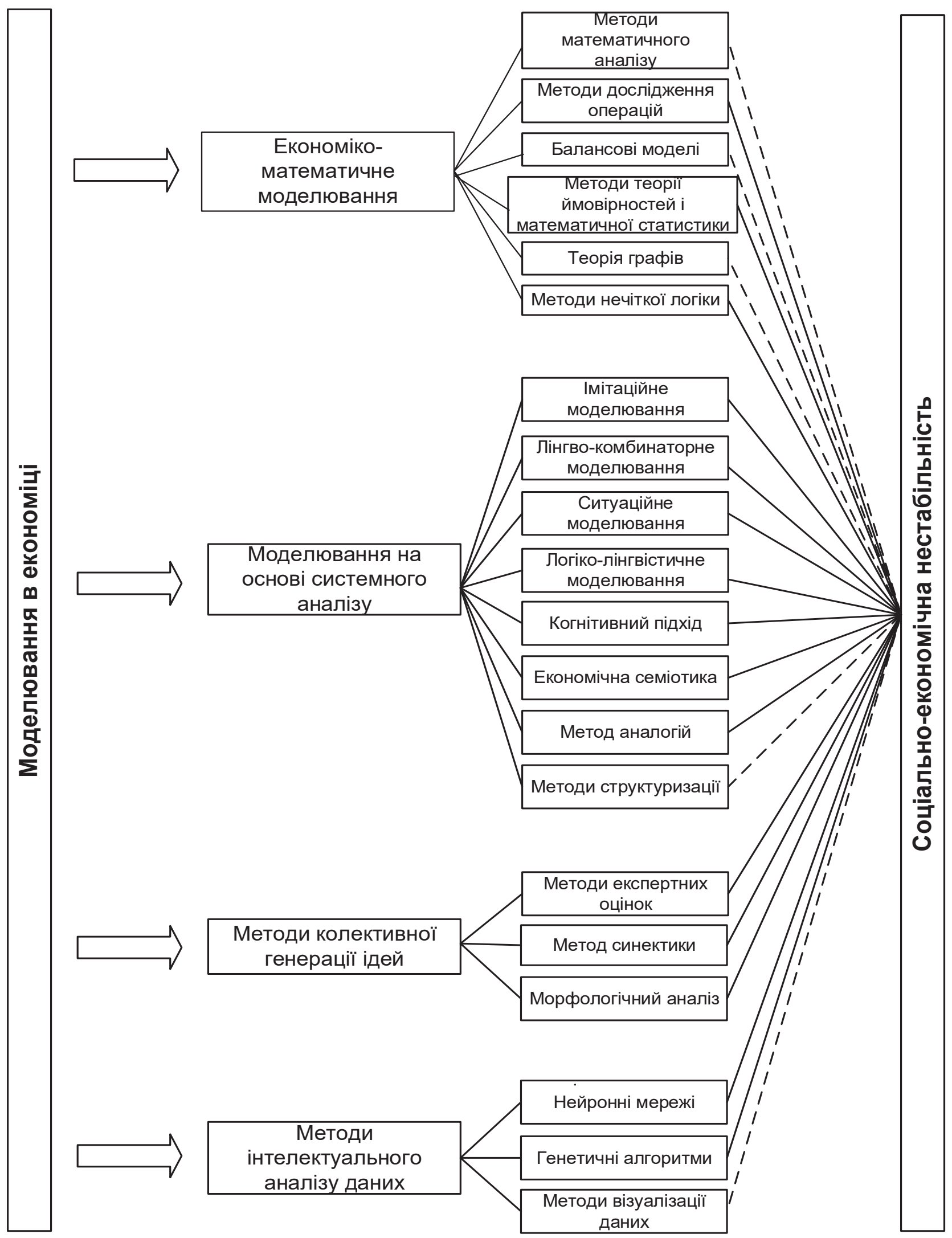

Рис. 1. Класифікація методів моделювання економіки з можливістю врахування соціально-економічної нестабільності 
Висновки. В даний час можна сказати, що методології застосування математики в природничих науках досить глибоко розвинуті. При моделюванні в економіці виникає багато спільного з фізичними процесами, але розвиток соціально-економічної системи стохастичний i багатовекторний, тому з'являється багато проблем при виборі метода моделювання та прогнозування. Це пояснюється в першу чергу тим, що об'єктом дослідження є не тільки виробничі процеси, а й виробничі відносини, поведінка персоналу, їх цілі та рішення, які вони приймають в різних ситуаціях. По-друге, при моделюванні процесів функціонування складних соціально-економічних систем виникає необхідність врахування внутрішніх та зовнішніх викликів, нестабільності зовнішнього середовища, факторів ризику та кризових станів. Жоден метод моделювання не здатен описати в повній мірі всі існуючі аспекти діяльності елементів системи адекватно реальному стану. Поєднання різних економіко-математичних методів в сукупності з сучасним програмним забезпеченням дозволять отримати найбільш точні результати моделювання для прийняття раціональних управлінських рішень.

\section{References:}

1. Borysova, S. Ye., Balashova, O. V. (2017). Ekonomiko-matematychne modelyuvannya ta prognozuvannya obsyagiv kredytnykh i zaluchenykh koshtiv bankivskoyi ustanovy [Economic-mathematical modeling and forecasting the volumes of credit and borrowed funds banking institutions]. Ekonomichnyj visnyk Donbasu [Economic Herald of the Donbas], 3 (49), 75-82. [in Ukrainian].

2. Stavyczkyj, O. V., Mozolevska, M. O. (2017). Vykorystannya nejronnykh merezh dlya prognozuvannya u finansovij sferi [Using neural for forecasting in the financial sector]. Aktualni problemy ekonomiky ta upravlinnya [Actual problems of economics and management], 11. <https://eujem.cz/wpcontent/uploads/2020/eujem_2020_6_3/09.pdf> (2020, July, 28). [in Ukrainian].

3. Fartushnyj, I. D., Puzyrna, K. M. (2017). Ekonomiko-matematychne modelyuvannya vyrobnychoyi diyalnosti pidpryyemstva lehkoyi promyslovosti [Economic-mathematical modeling of manufacturing activity in the light industry enterprise]. Ekonomichnyj visnyk NTUU KPI [Economic bulletin of national technical university of ukraine Kyiv polytechnic institute], $14<$ http://ev.fmm.kpi.ua/article/view/108705> (2020, July, 28). [in Ukrainian].

4. Fedoryak, R. M., Tymchenko, O. P. (2015). Ekonomiko-matematychne modelyuvannya ocinyuvannya konkurentospromozhnosti pidpryyemstva $\mathrm{v}$ umovakh ekonomichnoyi kryzy [Economic modeling assessment of the competitiveness of enterprises in economic crisis]. Formuvannya rynkovykh vidnosyn $v$ Ukrayini [Market Relations Development in Ukraine], 12 (175), 133-137. [in Ukrainian].

5. Kolomyceva, O. V., Burceva, T. I., Palonna, T. A. (2016). Ekonomiko-matematychni metody v marketynhovij diyalnosti pidpryyemstva [Econometric methods in enterprise marketing activities]. Zbirnyk naukovykh pracz Cherkaskoho derzhavnoho tekhnolohichnoho universytetu [Proceedings of Scientific Works of Cherkasy State Technological University Series], 41 (1), 5-9. [in Ukrainian].

6. Sydor, G. V. (2016). Ekonomiko-matematychne modelyuvannya procesu kredytuvannya silskogospodarskoho vyrobnycztva [Economic modeling of lending process for agricultural production]. Visnyk ONU imeni I.I. Mechnykova [Odessa National University Herald], 21, 7 (1), 187-191. [in Ukrainian].

7. Plaskon, S. A., Karmelyuk, G. I., Seniv, G. V. (2016). Matematychne modelyuvannya procesu funkcionuvannya ahrarnykh formuvan [Mathematical modelling of the process of agricultural units functioning]. Ekonomichnyj analiz [Ekonomichnyy analiz], 26, 1, 156-162. [in Ukrainian].

8. Loboda, O. M., Kavun, G. M. (2019). Ekonomiko-matematychni modeli dlya rozrahunku optymalnoyi specializaciyi ahrarnykh pidpryyemstv [Economic and mathematical models for calculating the optimal specialization of agricultural enterprises]. Biznes-Navihator [Business Navigator], 5-2, 141-145. [in Ukrainian].

9. Zhuravka, A. V., Mudashyru, T. M. (2017). Modeli nelinijnoyi dynamiky u vyrishenni problem makroekonomichnoyi nestabilnosti na rynku praci ta kapitalu [Models of nonlinear dynamics in solving problems of macroeconomic instability in the labor market and capital]. Molodyj vchenyj [Young Scientist], 4.4, 51-55. [in Ukrainian].

10. Duplyak, O. M., Yedlichko, A. O. (2016). Analiz pidkhodiv do modelyuvannya ta prohnozuvannya zarobitnoyi platy [Analysis approaches to modeling and forecasting wage]. Naukovyj visnyk Uzhgorodskoho nacionalnoho universytetu [Uzhorod National University Herald], 6 (1), 117-119. [in Ukrainian].

11. Vertelyeva, O. V. (2019). Matematychne modelyuvannya ekonomichnykh procesiv v umovakh paradyhmalnykh zrushen [Mathematical modeling of economic processes in conditions of paradigmal dispatches]. Investyciyi: praktyka ta dosvid [Investytsiyi: praktyka ta dosvid], 12, 48-56. [in Ukrainian].

12. Dantzig, G. B., Thapa, M. N. (1997). Linear programming. Springer-Verlag, 1. [in English].

13. Kumar, A. (2011). A new method for solving fully fuzzy linear programming problems. Applied Mathematical Modelling, 35, 2, 817-823. [in English]. 
14. Von Neumann, J., Morgenstern, O. (1944). Theory of games and economic behavior. Princeton University Press. [in English].

15. Naumova, M. A. (2018). Analiz transformacij u sferi zajnyatosti Ukrayiny v umovakh socialno-ekonomichnoyi nestabilnosti [Analysis of transformations in the sphere of employment of Ukraine in the conditions of social-economic instability]. Visnyk Odeskoho nacionalnoho universytetu [Odessa National University Herald], 23, 2, 82-90. [in Ukrainian].

16. Zadeh, L. A. (1965). Fuzzy sets. Information and Control, 8 (3), 338-353. [in English].

17. Forrester, J. (1971). Counterintuitive behavior of social systems. Technology Review, 73 (3), 52-68. [in English].

18. Matloff, N. (2008). Introduction to Discrete-Event Simulation and the SimPy Language.

$<$ https://web.cs.ucdavis.edu/ matloff/matloff/public_html/156/PLN/DESimIntro.pdf> (2020, July, 28).

[in English]. 